\title{
ANALIZA PORÓWNAWCZA PODEJŚĆ W ZAKRESIE ZARZĄDZANIA PROJEKTAMI
}

\begin{abstract}
Zarządzanie projektami stanowi współcześnie istotną część aktywności w różnego typu organizacjach, od przedsiębiorstw poczynając, przez podmioty non-profit, na instytucjach publicznych kończąc. W krajach wysokorozwiniętych wykształciła się kultura projektowa, bazująca zarówno na metodykach ogólnych, jak i specyficznych, optymalizowanych pod kątem danej branży. Kompetencje projektowe stanowią współcześnie ważny element kształcenia menedżerów. Są także czynnikiem ocenianym w rozmowach kwalifikacyjnych.

Celem artykułu jest przedstawienie analizy porównawczej wybranych, ogólnych metodyk i podejść w zakresie zarządzania projektami. Zidentyfikowano interesujące wymiary porównań, ważne zarówno z punktu widzenia kształtowania indywidualnej kariery kierownika projektu, jak i procesu zarządzania przebiegiem przedsięwzięć. Intencją autorów nie jest znalezienie najbardziej odpowiedniego rozwiązania, ponieważ musi być ono dostosowane do warunków i specyficznych potrzeb organizacji. Dążono jednak do przedstawienia informacji w sposób skoncentrowany, tak aby ułatwić świadomy i celowy dobór poszczególnych podejść.

We wprowadzeniu odniesiono się do genezy zarządzania projektami. Następnie przedstawiono specyfikę projektu oraz wymagania, które z niego wynikają względem procesu zarządzania. W kolejnych punktach artykułu przedstawiono również porównanie klasycznych podejść liniowych oraz wywodzących się z branży IT tzw. podejść zwinnych. Na podstawie tego ogólnego podziału porównano szczegółowo wybrane koncepcje zarządzania projektami, uwzględniając ich specyfikę oraz warunki kształtowania kompetencji.
\end{abstract}

Słowa kluczowe: zarządzanie projektami, PMI, PRINCE2, IPMA, scrum.

\section{WPROWADZENIE - GENEZA ZARZĄDZANIA PROJEKTAMI}

Rola projektów we współczesnych organizacjach, zarówno gospodarczych, jak i tych, które nie są nastawione na zysk, jest powszechnie akceptowana i rozwijana. Konsekwencją zainteresowania zarządzaniem projektami jest upowszechnianie istniejącej wiedzy na ten temat, a także tworzenie i aplikacja nowych koncepcji, narzędzi, modeli i standardów33. Zjawisko projektu znane jest już od najdawniejszych czasów ${ }^{4}$. Historia realizacji projektów kształtowała się wraz z rozwojem cywilizacji, pozostawiając ślady w postaci piramid,

\footnotetext{
${ }^{1}$ J. Strojny, dr, Katedra Ekonomii, Politechnika Rzeszowska, Rzeszów, e-mail: jstrojny@prz.edu.pl (autor korespondencyjny).

${ }^{2}$ K. Szmigiel, absolwentka studiów licencjackich na specjalności Zarządzanie Projektami na Wydziale Zarządzania Politechniki Rzeszowskiej, e-mail: szmigielkinga@gmail.com

${ }^{3}$ T.J. Rodney, R. Müller, On the nature of the project as a temporary organization, "International Journal of Project Management", 21/1 (2003), s. 1 - 8.

${ }^{4}$ A. Kozarkiewicz, Zarządzanie portfelami projektów, PWN, Warszawa 2012, s. 17 - 18.
} 
linii kolejowych, drapaczy chmur czy rakiet kosmicznych, a nawet operacji wojskowych ${ }^{5}$. Prekursorów zarządzania projektami można szukać już wśród starożytnych społeczeństw ${ }^{6}$ : Sumerów, Egipcjan, Babilończyków, Rzymian, jak również Chińczyków.

Dopiero w XX w., kiedy świat biznesu stawał się coraz bardziej złożony, zaczęto systematyzować wiedzę oraz wprowadzać konkretne techniki i narzędzia w zakresie zarządzania projektami. Duże projekty rządowe, niemożliwe do zarządzania za pomocą tradycyjnych metod, dawały impulsy do implementacji rozwiązań, które stały się podstawą metodologii zarządzania projektami. Na przełomie XIX i XX wieku Frederick W. Taylor, prowadząc badania nad wydajnością pracowników, doszedł do wniosku, że każdą pracę można podzielić na mniejsze fragmenty. Do tej pory jedynym sposobem polepszenia efektywności było wymaganie od zatrudnionych cięższej i dłuższej pracy, Taylor wprowadził natomiast pojęcie wydajności pracy ${ }^{7}$. Mniej więcej w tym samym okresie jego bliski współpracownik Henry Gantt skupił się na śledzeniu kolejności poszczególnych zadań, składających się na realizację złożonych przedsięwzięć. Wynikiem jego analiz są tak zwane wykresy Gantta, przedstawiające graficzny rozkład czynności w czasie, sporządzane zarówno dla pracownika, jak i dla całego przedsięwzięcia ${ }^{8}$.

Pierwszym impulsem nowoczesnego zarządzania projektami była realizacja w latach II wojny światowej amerykańskiego projektu pod kryptonimem Manhattan, poświęconego budowie bomby atomowej ${ }^{9}$. Okres ten niósł ze sobą urzeczywistnianie licznych przedsięwzięć militarnych z zakresu przemysłu zbrojeniowego, doskonalenia lotnictwa czy budowy okrętów. Ich kompleksowość, znaczenie oraz ogrom zaangażowanych zasobów, a także ograniczony dopływ siły roboczej i presja czasu spowodowały, że zaczęto szukać nowych, bardziej efektywnych technik organizacji i zarządzania. Ze względu na tajemnicę wojskową początkowo metody te nie były upowszechniane, po wojnie zaś zastosowano je ponownie i udoskonalono w amerykańskich siłach powietrznych i marynarce wojennej przy konstrukcji pierwszej nuklearnej łodzi podwodnej (projekt Polaris) oraz w rozwoju lotów kosmicznych (projekt Apollo) ${ }^{I 0}$. Pod koniec lat czterdziestych XX wieku odbyły się pierwsze, cywilne zastosowania procedur zarządzania projektami w związku z uruchomieniem przez Stany Zjednoczone programów pomocowych dla Europy w ramach planu Marshalla, na przełomie lat pięćdziesiątych i sześćdziesiątych zaś stosowano je już dość powszechnie $\mathrm{w}$ wielu innych przedsięwzięciach. Wynikiem zdobytych wcześniej doświadczeń było powstanie nowych struktur organizacyjnych oraz opracowanie podstawowych metod zarządzania projektami.

Wraz z upływem czasu zastosowane narzędzia organizacji pracy i zarządzania rozpowszechniły się we wszystkich gałęziach przemysłu. Czołowe firmy poszukiwały bowiem nie tylko nowych strategii konkurowania, ale także wydajnych technik wspomagających

\footnotetext{
${ }^{5}$ T. Seymour, S. Hussein, The History of Project Management, "International Journal of Management\& Information Systems", 18/4 (2013), 233 - 240.

${ }^{6}$ K. Frączkowski, Zarządzanie projektem informatycznym, Oficyna Wydawnicza Politechniki Wrocławskiej, Wrocław 2003, s. 9 - 10.

${ }^{7}$ http://support.office.com/pl-pl/article/Historia-zarz\%C4\%85dzania-projektami-a2e0b717-094b-4d1e-878a-fcd0 978891cd (dostęp: 20.11.2014)

${ }^{8}$ Ibidem.

${ }^{9}$ Więcej: Y.H. Kwak, A brief history of Project Management, [w:] The story of managing projects, red. G. Carayannis, Y.H. Kwak, FT. Anbari, Quorum Books, USA 2003

${ }^{10}$ A. Kozarkiewicz, op. cit., s. 18.
} 
proces zarządzania w coraz bardziej skomplikowanym otoczeniu ${ }^{11}$. Jeżeli chodzi o uznanie zarządzania projektami za odrębną metodę, to na tym polu duży wkład mają liczne stowarzyszenia doradców, takie jak Project Management Institute (PMI), oraz International Project Management Association (IPMA). Ważnymi osiągnięciami tego typu organizacji, skupiających profesjonalistów w zakresie zarządzania projektami, są opracowanie standardów oraz popularyzacja najlepszych praktyk. Stanowią one zestaw nie tylko ogólnych ram, ale również szczegółowych procedur wspierających omawiane procesy ${ }^{12}$. Dzięki temu, aktualnie zarządzanie projektami jest kompletną i rozbudowaną, a co najważniejsze - wciąż rozwijaną metodą zarządzania ${ }^{13}$. Dysponuje ona szerokim systemem kształcenia, sprawdzonymi w praktyce metodami oraz licznymi organizacjami, rozwijającymi i propagującymi wiedzę o zarządzaniu projektami.

\section{PROJEKT - CECHY I ROLA WE WSPÓŁCZESNEJ ORGANIZACJI}

W rezultacie nieustannych zmian, każda organizacja staje w obliczu nowych problemów będących konsekwencją pojawienia się szans lub zagrożeń. Jedne są postrzegane jako coś pozytywnego i wiążą się z wykorzystaniem powstałych możliwości (np. rozwój produktu, zdobycie nowych segmentów rynku, czy też podpisanie korzystnej długoterminowej umowy). Inne zaś mogą wywołać skutki negatywne, którym należy zapobiec (np. utrata rynku, brak konkurencyjności oferty, zbyt wysokie koszty funkcjonowania itp.). Tego typu wyzwania rodzą potrzebę, która następnie wyznacza obraz pożądanej sytuacji w przyszłości i definiuje cele niezbędne do jej osiągnięcia, a sama droga dotarcia do pożądanego stanu jest procesem, określanym mianem projektu ${ }^{14}$.

Projekty mogą mieć różnorodną postać, a ich zakres może znacząco różnić się od siebie. Początkowo projekty miały charakter głównie konstrukcyjno-techniczny. Obecnie występują one praktycznie we wszystkich dziedzinach aktywności ludzkiej: w gospodarce, administracji publicznej, nauce, edukacji, kulturze, obronności, sporcie itd. Zostało to wymuszone przede wszystkim zmianami w funkcjonowaniu organizacji związanymi z globalizacją otoczenia oraz drastycznym wzrostem zasobów informacji towarzyszących działalności firm. Co więcej, konieczne jest szybkie i elastyczne reagowanie na zmiany zachodzące w otoczeniu rynkowym, także na gwałtowny rozwój nowoczesnych technologii $^{15}$.

W literaturze z zakresu zarządzania projektami istnieje wiele różnorodnych definicji pojęcia ,,projekt”. Na szczególną uwagę zasługuje często cytowana w literaturze światowej krótka i ogólna definicja sformułowana przez amerykański PMI według której ,,projekt jest tymczasowym przedsięwzięciem mającym na celu stworzenie unikalnego produktu lub usługi"16. Aby dane przedsięwzięcie mogło być nazwane projektem muszą zostać zidentyfikowane pewne, określone atrybuty działania. Do najważniejszych cech projektu należy zatem zaliczyć: celowość, tymczasowość, złożoność i niepowtarzalność.

\footnotetext{
11 A.K. Munns, B.F. Bjeirmi, The role of project management in achieving project success, "International, Journal of Project Management", 14/2 (1996), s. 81 - 87.

${ }^{12}$ A. Kozarkiewicz, op. cit., s. 20.

${ }^{13}$ J. Strojny, Zarządzanie projektami innowacyjnymi, Politechnika Rzeszowska, Rzeszów 2012.

14 E. Małyszek, Zarzadzanie projektami (Project Management) w mikro- $i$ matych przedsiębiorstwach, http://www.lbs.pl/projekt/dobrepraktyki2011/files/artykuly/art._Malyszek.pdf, s. 77 (dostęp: 1.12. 2014).

${ }^{15}$ http://akson.sgh.waw.pl/ darry/PM/Texts/introduction.html (dostęp: 1.12.2014).

${ }^{16}$ Ibidem.
} 
Projekt jest realizowany w sposób względnie niezależny w stosunku bieżącej działalności przedsiębiorstwa, ma specyficzną strukturę organizacyjną i nierozłącznie wiąże się z występowaniem ryzyka. Jego urzeczywistnienie wymaga zastosowania specjalnych metod i technik oraz zaangażowania znacznych, lecz limitowanych środków rzeczowych, ludzkich i finansowych na rzecz przeciwdziałania zagrożeniom. Projekt często charakteryzuje się dużą złożonością i jest najczęściej wdrażany interdyscyplinarnie przez wysoko wykwalifikowanych specjalistów.

Każdy projekt, niezależnie od zastosowanego podejścia, ma precyzyjnie określone wymagania definiowane przez trzy współzależne parametry tworzące tzw. „,sztywny trójkąt" "17. Są nimi: zakres (zadania konieczne do wykonania dla osiągnięcia danego celu), koszt (nakłady związane z realizacją wymaganych działań) oraz czas (okres potrzebny do ich urzeczywistnienia zamierzeń). Z tych trzech wymiarów wynika czwarty, który ogólnie można określić jako jakość (zgodność rezultatów z oczekiwaniami). Zmiana któregokolwiek wyróżnika tworzącego trójkąt celów pociąga za sobą konieczność modyfikacji przynajmniej jednego z pozostałych. ${ }^{18}$. Zarządzanie projektem zatem można najprościej określić jako podejmowanie działań niezbędnych do efektywnego osiągnięcia celów projektów, najczęściej w warunkach permanentnego ryzyka. Z wymagań tego procesu wynikają pozostałe obszary zarządzania projektem - motywowanie zespołu projektowego, dbanie o właściwą komunikację pomiędzy uczestnikami, planowanie i controlling rzeczowofinansowy, itd. ${ }^{19}$. Takie podejście zapewnia osiągnięcie zamierzeń projektu w zakładanym czasie oraz przy określonych kosztach ${ }^{20}$. W celu uzyskania efektywności przedsięwzięcia konieczne jest zastosowanie optymalnych technik, w których doborze pomocne okazują się zbiory zasad dotyczące sposobu wykonywania danej pracy lub trybu postępowania, zwane metodykami zarządzania, omówione szczegółowo w następnych rozdziałach. Ważne jest także odpowiednie przygotowanie całej organizacji, a więc stworzenie pewnego rodzaju systemu zarządzania projektami ${ }^{21}$.

\section{PRZEGLĄD GŁÓWNYCH KONCEPCJI ZARZĄDZANIA PROJEKTAMI}

Zarządzanie projektami, od wielu lat podlega zmianom w kierunku profesjonalizacji i wytworzenia standardów branżowych. Efektem tych procesów jest bogactwo norm i zasad zarówno na poziomie globalnym, jak i lokalnym, określających sposób zarządzania projektami. Tego typu aktywność stała się poważną profesją, w której znajomość metodyk i technik wyznaczanych przez międzynarodowe stowarzyszenia fachowe odgrywa priorytetową rolę dla konkurencyjności zarówno firmy, jak i jej pracowników na ryn-

\footnotetext{
${ }^{17}$ Sztywny trójkąt - zwany inaczej magicznym trójkątem, trójkątem ograniczeń, współzależności, zakresu projektu.

${ }^{18}$ E. Małyszek, op. cit., s. 78.

${ }^{19}$ Z. Miśtal, Zarzadzanie projektami w muzeum na przykładzie Muzeum Historycznego Miasta Krakowa, [w:] Zarzadzanie $w$ kulturze, t. 10, red. E. Orzechowski i K. Plebańczyk, Wydawnictwo Uniwersytetu Jagiellońskiego, Kraków 2009, s. 158.

20 K. Borowska, Zastosowanie metody Project Cycle Management $w$ zarzadzaniu projektami wspótfinansowanymi ze środków unijnych, [w:] Heraditas Mercaturae. Księga pamiątkowa dedykowana świętej pamięci profesorowi S. Miklaszewskiemu, red. P. Czubik i Z. Mach, Instytut Multimedialny, Kraków 2012, s. 146

${ }^{21}$ Więcej: E.S. Andersen, S.A. Jessen, Project maturity in organisations, "International Journal of Project Management", 21/6 (2003), s. 457 - 461, T. Cooke-Davies, Project management maturity models, [w:] The Wiley guide to managing projects, red. P. Morris, Peter, J.K. Pinto, John Wiley \& Sons, Hoboken, NJ, 2004, s. 1234 - 1255, J. Lampel, P.J. Pushkar, Models of project orientation in multiproject organizations, [w:] op. cit., 223 - 236.
} 
ku pracy ${ }^{22}$. Różnorodne metodyki zarząadzania projektami stanowią źródło najlepszych praktyk pełniących funkcję standardów i procedur opisujących działania i procesy, jakie kierownik projektu i inni jego uczestnicy muszą podjąć, aby zrealizować go z sukcesem ${ }^{23}$. Innymi słowy jest to zestaw wskazówek, zasad i reguł wyznaczających sposób postępowania przy wykonywaniu projektów w zakresie działań zarządczych, a także w sensie zewnętrznej ramy organizacyjnej całego przedsięwzięcia, która zapewni skuteczność planowania, monitorowania i sterowania przebiegiem prac $^{24}$.

Bogaty dorobek zarządzania projektami pozwala wyróżnić mnóstwo różnorodnych metodyk - jedne z nich są uniwersalne, mogą być stosowane przez organizacje różnego typu działające w wielu odmiennych gałęziach gospodarki, inne stanowią grupę metodyk sektorowych, dostosowanych do poszczególnych działów, na przykład informatyki, budownictwa czy administracji rządowej, jeszcze inne zaś dotyczą metodyk firmowych, czyli wypracowanych i stosowanych w organizacjach, w których projekty są podstawą funkcjonowania (np. metodyka zarządzania programami i projektami kosmicznymi Narodowej Agencji Aeronautyki i Przestrzeni Kosmicznej - National Aeronautics Space Administration $)^{25}$. Jeden $\mathrm{z}$ podstawowych podziałów metodyk wyróżnia tradycyjne oraz zwinne metodyki zarządzania projektami.

Tradycyjne metodyki zarządzania projektami, zwane inaczej sekwencyjnokaskadowymi, oparte na cyklu życia projektu, w którym identyfikuje się sekwencję kroków, jakie muszą zostać podjęte dla realizacji danego przedsięwzięcia. Podejście to sprawdza się zwłaszcza w sytuacjach, w których cel wraz z techniką jego osiągnięcia są jasne i w pełni zdefiniowane, a ponadto istnieje małe prawdopodobieństwo zmiany zakresu w trakcie trwania projektu. Innymi słowy, bazuje ono na założeniu, że klient „wie, czego chce" już od samego początku i potrafi to wyrazić w czytelnych, jednoznacznych, ścisłych i mierzalnych wymaganiach ${ }^{26}$. Mocnymi stronami takiego podejścia są zatem: określony plan dla całego przedsięwzięcia, brak potrzeby zespołu o wysokich kompetencjach oraz znane wymagania dotyczące zasobów. Do głównych słabości można zaliczyć natomiast: ograniczoną możliwość wprowadzania zmian w trakcie projektu, konieczność tworzenia bardzo szczegółowych planów, ryzyko wysokich kosztów i przedłużania się projektu, nadmierny poziom formalizacji oraz brak koncentracji na rzeczywistych potrzebach klienta i dostarczanej wartości ${ }^{27}$. Grupa metodyk klasycznych istnieje od dawna, a reżim, jaki nakładają na rozwój projektu, dyscyplinuje w pewnym sensie sposób postępowania w trakcie jego realizacji. Nie daje to jednak gwarancji jego zakończenia sukcesem - podejścia te są tak bardzo „sztywne” i ustrukturyzowane, że przestrzeganie wszystkich kroków, formuł i procedur może znacząco spowalniać proces realizacji danego przedsięwzięcia $^{28}$.

\footnotetext{
${ }^{22}$ P. Wyrozębski, Zarzadzanie wiedza..., Difin, Warszawa 2014, s.205.

${ }^{23}$ Ibidem,

${ }^{24}$ P. Habela, Metodyki zarzadzania projektem, PJWSTK, Warszawa 2011, s. 4.

${ }^{25}$ K. Kozioł-Nadolna, Metodyki zarzadzania projektami, [w:] Zarzadzanie projektami w organizacji, red. K. Janasz i J. Wiśniewska, Wyd. Difin, Warszawa 2014, s. 154.

${ }^{26} \mathrm{http}: / /$ www.4pm.pl/artykuly/przyjrzyjmy-sie-tradycyjnym-projektom (dostęp: 15.02.2015)

27 T. Kopczyński, Rola $i$ kompetencje kierownika projektu $w$ zwinnym zarzadzaniu projektami na tle tradycyjnego podejścia do zarzadzania projektami, „Studia Oeconomica Posnaniensia”, 270/9 (2014), s. 103.

${ }^{28} \mathrm{~W}$. Chmielarz, Kryteria wyboru metod zarzadzania projektami informatycznymi, „Problemy Zarządzania”, $38 / 3$ (2012), s. 32.
} 
Na gruncie krytyki i odpowiedzi na tradycyjne, sekwencyjne metody, w ostatnich latach zaczęły się kształtować nowe trendy zwane metodykami zwinnymi (adaptacyjnymi, elastycznymi) - Agile Project Management (APM) ${ }^{29}$. Ich źródeł należy szukać głównie w problemach realizacji projektów informatycznych, których specyfika i podatność na niekontrolowane zmiany zakresu powodowały dramatycznie niski odsetek ukończenia z powodzeniem ${ }^{30}$. Są one zatem próbą dostosowania się do nowych warunków gospodarczych determinowanych przede wszystkim postępem technologicznym, globalizacją rynków i zaostrzającą się konkurencją. Zwinne zarządzanie projektami opiera się na poczynaniach dodających wartość, a także eliminujących niepotrzebne czynności zarówno administracyjne, jak i te, które zapewniają zgodność z formalnymi wymogami. Miejscem, gdzie znajdują one najlepsze zastosowanie, są te środowiska, w których występuje duża niepewność i nie ma możliwości dokładnego zaplanowania całości projektu w odpowiednim czasie, a ponadto są wymagane znaczne twórcze zaangażowanie wysoko wykwalifikowanych pracowników i wysoki poziom interakcji zespołowej. Szczegółowe porównanie podejścia zwinnego i tradycyjnego przedstawiono w tabeli 1.

Tabela 1. Porównanie założeń tradycyjnego i zwinnego podejścia do zarządzania projektami.

\begin{tabular}{|c|c|c|}
\hline Parametry & Podejście tradycyjne & Podejście zwinne \\
\hline Zorientowanie & $\begin{array}{c}\text { na proces i podziałał zadań, } \\
\text { na procedury kontroli oraz narzędzia i techniki } \\
\text { wspomagające realizację. }\end{array}$ & $\begin{array}{c}\text { na interesariuszy projektu i dostarczanie } \\
\text { funkcjonalności. }\end{array}$ \\
\hline $\begin{array}{l}\text { Oczekiwania } \\
\text { klientów }\end{array}$ & $\begin{array}{l}\text { jasno udokumentowane i dobrze rozumiane, } \\
\text { najlepiej niezmienne w czasie. }\end{array}$ & $\begin{array}{l}\text { odkrywane w toku kolejnych iteracji projek- } \\
\text { tu. }\end{array}$ \\
\hline Rezultaty & $\begin{array}{c}\text { wyrażone liczbowo (procentowo) } \\
\text { w pełni przewidywalne. }\end{array}$ & $\begin{array}{c}\text { mało przewidywalne z powodu realizacji } \\
\text { niezdefiniowanych działań. }\end{array}$ \\
\hline $\begin{array}{l}\text { Podejście do } \\
\text { problemu i } \\
\text { celów projek- } \\
\text { towych }\end{array}$ & $\begin{array}{c}\text { plany są przewidywaniem przyszłości, } \\
\text { · szczegółowo zdefiniowane i precyzyjnie } \\
\text { kreślone cele bazujące na metodzie SMART, } \\
\text { · kaskada celów długo- i krótkoterminowych } \\
\text { opartych na dogłębnej analizie potrzeb. }\end{array}$ & $\begin{array}{l}\text { plany są hipotezą, spekulacją na przyszłość a } \\
\text { nie przewidywaniem, } \\
\text { · opracowanie wizji o charakterze ogólnym } \\
\text { (koncepcja tego, co ma być końcowym efek- } \\
\text { tem projektu). } \\
\end{array}$ \\
\hline $\begin{array}{l}\text { Cykl zarządza- } \\
\text { nia projektem }\end{array}$ & $\begin{array}{c}\text { deterministyczny i liniowy, oparty na precy- } \\
\text { zyjnie określonych etapach projektowych, } \\
\text { zdefiniowane kluczowe procesy projektowe, } \\
\text { planowanie oparte na drobiazgowym harmo- } \\
\text { nogramie stanowiącym podstawę zarządzania } \\
\text { projektem; }\end{array}$ & $\begin{array}{c}\text { iteracyjny i empiryczny, oparty na dostar- } \\
\text { czaniu elementów funkcjonalności, } \\
\text { krótkie harmonogramy procesu tworzenia } \\
\text { wartości, } \\
\text { · adaptacyjność i dostosowywanie się do } \\
\text { zmiennych warunków, } \\
\text {. procesy maksymalnie uproszczone. }\end{array}$ \\
\hline $\begin{array}{l}\text { Aspekt organi- } \\
\text { zacyjny pro- } \\
\text { jektu }\end{array}$ & $\begin{array}{c}\text { organizacja pracy wnikliwie sprecyzowana na } \\
\text { podstawie struktury podziału pracy, } \\
\text {. wysoki poziom formalizmu, } \\
\text {. obszerna dokumentacja, } \\
\text {. dokładnie określona struktura organizacyjna, } \\
\text {. orientacja na równowagę między ogranicze- } \\
\text { niami: koszt, jakość i czas. }\end{array}$ & $\begin{array}{l}\text { nieskomplikowana organizacja pracy, nasta- } \\
\text { wiona na elastyczność, szybkość i przysto- } \\
\text { sowawczość, } \\
\text { · zakłada się łatwe zmiany modelowe dosto- } \\
\text { sowywane do bieżących potrzeb i następują- } \\
\text { ce w różnych terminach, } \\
\text {. niski stopień sformalizowania. }\end{array}$ \\
\hline $\begin{array}{l}\text { Koszty projek- } \\
\text { tu }\end{array}$ & - oszacowany dokładnie budżet całego projektu. & $\begin{array}{l}\text { oszacowany konkretnie budżet tylko dla } \\
\text { pierwszego etapu projektu, } \\
\text { kolejne etapy - ogólna prognoza wydatków. }\end{array}$ \\
\hline $\begin{array}{l}\text { Aspekt perso- } \\
\text { nalny oraz }\end{array}$ & $\begin{array}{c}\text { praca oparta na wąskiej specjalizacji, } \\
\text { wysokie kompetencje zespołu projektowego, }\end{array}$ & $\begin{array}{l}\text { praca bazująca na małych, samodyscyplinu- } \\
\text { jących się i samoorganizujących zespołach, }\end{array}$ \\
\hline
\end{tabular}

\footnotetext{
${ }^{29}$ T. Kopczyński, op. cit., s. 102.
}

${ }^{30}$ P. Wyrozębski, op. cit., s. 237. 


\begin{tabular}{|c|c|c|}
\hline Parametry & Podejście tradycyjne & Podejście zwinne \\
\hline $\begin{array}{l}\text { zespołu projek- } \\
\text { towego }\end{array}$ & $\begin{array}{c}\text { zwłaszcza w obszarze wiedzy i doświadczeń, } \\
\text { styl kierowania demokratyczny (integracyjny) } \\
\text { uzależniony od specyfiki projektu oraz insty- } \\
\text { tucjonalnej formy jego realizacji, mocno na- } \\
\text { stawiony na zadania, } \\
\text { kierownik projektu skupiony przede wszyst- } \\
\text { kim na budżecie, harmonogramie i zakresie } \\
\text { projektu, } \\
\text { restrykcyjność zarządzania. }\end{array}$ & $\begin{array}{c}\text { - silny nacisk na współpracę, komunikację i } \\
\text { integrację członków zespołu, } \\
\text { bliska współpraca z klientami oraz włączenie } \\
\text { ich do procesu tworzenia wartości końcowej, } \\
\text { - zarządzanie przywódczo-współpracujące } \\
\text { oparte na sterowaniu, a nie kontrolowaniu, } \\
\text { kierownik projektu skupiony na dostarczeniu } \\
\text { rezultatów, a tradycyjne ograniczenia trak- } \\
\text { towane sa jako wtórne. }\end{array}$ \\
\hline $\begin{array}{l}\text { Pojęcie sukce- } \\
\text { su }\end{array}$ & $\begin{array}{l}\text { sukces rozumiany jako zgodność z wcześniej } \\
\text { założonym planem. }\end{array}$ & $\begin{array}{c}\text { sukcesem jest zdolność adaptacji do zmie- } \\
\text { niających się warunków w projekcie. }\end{array}$ \\
\hline $\begin{array}{l}\text { Odchylenia od } \\
\text { planu }\end{array}$ & $\begin{array}{l}\text { są traktowane jako konsekwencje błędnego } \\
\text { zarządzania, } \\
\text { wymagają bezkrytycznej poprawy, podjęcia } \\
\text { działań naprawczych (podejście korekcyjne), }\end{array}$ & $\begin{array}{c}\text { przyczyny odchyleń stanowią podstawę } \\
\text { analizy i wniosków na przyszłość, } \\
\text { są podstawą do zmiany planu kolejnych faz } \\
\text { projektu (podejście adaptacyjne). }\end{array}$ \\
\hline $\begin{array}{l}\text { Spojrzenie na } \\
\text { zarządzanie } \\
\text { zmianą }\end{array}$ & $\begin{array}{l}\text { ogranicza się je często do biurokratycznych } \\
\text { procedur blokujących zmianę, } \\
\text { trudności z wprowadzaniem zmian, ścisłe } \\
\text { skoncentrowanie na planie początkowym. }\end{array}$ & $\begin{array}{l}\text {. jest motorem dla procesów innowacyjnych; } \\
\cdot \text { otwartość na zmiany, } \\
\text {. elastyczne i adaptacyjne podejście do zmian. }\end{array}$ \\
\hline $\begin{array}{l}\text { Zarządzanie } \\
\text { ryzykiem }\end{array}$ & $\begin{array}{l}\text { niski stopień wystąpienia ryzyka - możliwa } \\
\text { identyfikacja rodzajów ryzyka powszechnie } \\
\text { występujących dla poszczególnych działań. }\end{array}$ & $\begin{array}{l}\text { możliwość wystąpienia rodzajów ryzyka } \\
\text { niezdefiniowanych, szczególnie w ramach } \\
\text { niezaplanowanych wcześniej działań. }\end{array}$ \\
\hline Zastosowanie & $\begin{array}{l}\text { projekty rozwojowe miękkie i twarde (infra- } \\
\text { strukturalne na cele dydaktyki), } \\
\text { projekty badawcze twarde (infrastrukturalne } \\
\text { na cele badań). }\end{array}$ & $\begin{array}{c}\text { projekty badawcze miękkie dotyczące badań } \\
\text { naukowych, } \\
\text { projekty innowacyjne (testujące oraz upo- } \\
\text { wszechniające). }\end{array}$ \\
\hline
\end{tabular}

SMART (Specific, Measurable, Achievable, Realistic, Time-bound ) - skonkretyzowany, mierzalny, osiągalny, realny, określony w czasie

Źródło: opracowanie własne na podstawie: P. Wyrozębski, Elastyczne podejście do zarządzania projektami, [w:] Problemy wspótczesnej praktyki zarządzania, red. S. Lachiewicz i M. Matejun, Wydawnictwo Politechniki Łódzkiej, Łódź 2007, s. 151-152, T. Kopczyński, Rola i kompetencje kierownika projektu $w$ zwinnym zarzadzaniu projektami na tle tradycyjnego podejścia do zarzadzania projektami, „Studia Oeconomica Posnaniensia” 270/9 (2014), s. 105-106.

Praktyka zarządzania projektami przechodzi ostatnio wyraźną ewolucję. Odchodzi od podejścia tradycyjnego, które oparte jest na przewidywalności i klasycznym planowaniu, i składa się ku zwinnemu, w którym akcentowana jest adaptacyjność, kreatywność i szybkie działanie zorientowane na potrzeby klienta.

\section{PODSTAWOWE PODEJŚCIA DO ZARZĄDZANIA PROJEKTAMI - KRÓTKA CHARAKTERYSTYKA}

Obecnie organizacje, borykając się ze zmiennym otoczeniem, znacznym ograniczeniem środków oraz skróceniem czasu wytwarzania nowych produktów i usług, decydują się na zastosowanie sprawdzonych i uporządkowanych metod i rozwiązań z zakresu zarządzania projektami ${ }^{31}$. Wśród tradycyjnych podejść szczególną popularnością cieszą się następujące metodyki: PRINCE2, PMI oraz IPMA. Natomiast w ramach tak zwanych metodyk miękkich szczególnie znany jest SCRUM. Ich krótką charakterystykę przedstawiono w dalszej części artykułu.

31 A. Wodecka-Hyjek, Metodyka PRINCE2 w zarządzaniu realizacja projektów, [w:] Nurt metodologiczny w naukach o zarządzaniu. 50 lat pracy naukowej prof. zw. dr hab. Zofii Mikołajczyk, red. W. Błaszczyk, I. Bednarska-Wnuk, P. Kuźbik, Wydawnictwo Uniwersytetu Łódzkiego, Łódź 2010, s. 361. 
Metoda PRINCE2 (PRojects IN Controlled Environments) jest publicznie dostępna i niezastrzeżona prawnie, postrzegana na całym świecie, jako jedna z najszerzej akceptowanych metod zarządzania projektami. Wynika to głównie z tego, że jest ona na tyle ogólna, iż można ją zastosować do realizacji wszelkich projektów w przedsiębiorstwach i organizacjach dowolnej wielkości i branży, niezależnie od skali i rodzaju przedsięwzię$\mathrm{cia}^{32}$. Została ona stworzona i opublikowana po raz pierwszy w 1989 r. w Wielkiej Brytanii w wyniku doświadczeń agencji rządowej Central Computer and Telecommunications Agency (CCTA). Jej podstawowe założenia zaczerpnięto z metodyki opracowanej w 1975 r. przez prywatną firmę Simpact System Limited, znanej pod nazwą PROMPT (Project Resource Organisation Management and Planning Techniques) ${ }^{33}$. W 1996 r. powstała jej unowocześniona, jeszcze bardziej uniwersalna wersja, dostosowana do potrzeb projektów nie tylko informatycznych, zaś ostatnia, piąta edycja pochodzi z roku $2009^{34}$. Obecnie zdobyła ona olbrzymią popularność i uznanie w ponad 150 krajach, a ponadto jest zalecanym standardem w Unii Europejskiej, wdrażanym przez wszystkie struktury NATO. Mimo że jest ona własnością brytyjskiego rządu, jej stosowanie nie wymaga licencji, a bieżącym aktualizowaniem i dostosowywaniem zajmuje się Office of Government Commerce $(\mathrm{OGC})^{35}$.

Metoda PRINCE2 stanowi główną, lecz niewykluczającą alternatywę dla amerykańskiej metodyki PMI, opartej na wytycznych Project Management Body of Knowledge (PMBoK). Stosują ją z powodzeniem nie tylko wielkie międzynarodowe korporacje, ale także niewielkie firmy usługowe. W Polsce jest ona wciąż dosyć nowa, a jej głównym popularyzatorem jest Centrum Rozwiązań Menedżerskich S.A., które opracowało swoją wersję materiałów szkoleniowych SPOCE Ltd., akredytowanych przez APM Group ${ }^{36}$. Najbardziej uznanym zastosowaniem tej metodyki w Polsce jest projekt elektronicznej Platformy Usług Administracji Publicznej realizowany w Departamencie Informatyzacji Ministerstwa Spraw Wewnętrznych i Administracji. Wykorzystywana jest ona również w Kancelarii Sejmu Rzeczpospolitej Polskiej, Narodowym Banku Polskim oraz w Agencji Restrukturyzacji i Modernizacji Rolnictwa ${ }^{37}$. Metodyka PRINCE2 wyczerpująco określa role niezbędne do zarządzania przedsięwzięciem. Wyznacza także obowiązki oraz odpowiedzialność decyzyjną i wykonawczą. Wskazuje się również zasady takiego adoptowania metodyki, aby możliwe było jej dostosowywanie do stopnia złożoności danego projektu oraz możliwości organizacji ${ }^{38}$.

Project Management Institute (PMI) -to amerykańskie stowarzyszenie branżowe, które zostało założone w 1969 r., ma siedzibę w Stanach Zjednoczonych, jest jednocześnie największą, globalną organizacją zrzeszającą ludzi związanych z zarządzaniem projektami. Wolontariusze PMI zgromadzili się po raz pierwszy w 1983 r., aby wyodrębnić i sformułować najlepsze standardy w prowadzeniu projektów. W ten właśnie sposób po-

\footnotetext{
${ }^{32}$ http://www.prince2.akn.pl/Prince2_program.pdf (dostęp: 1.03.2015)

${ }^{33}$ PROMPT) - metodyka prowadzenia projektów informatycznych.

${ }^{34}$ OGC, Managing Successful Projects with PRINCE2TM, Office of Government Commerce, TSO, London 2009.

${ }^{35}$ K. Kozioł-Nadolna, op. cit., s. 154 - 155.

${ }^{36} \mathrm{http}: / /$ www.4pm.pl/artykuly/metodyka-zarządzania-projektami-prince2 (dostęp: 4.03.2015)

${ }^{37}$ A. Wodecka-Hyjek, op. cit., s. 363.

${ }^{38}$ Ibidem, s. 363-364.
} 
wstał PMBoK ${ }^{39}$, który stanowi przewodnik, pewien kanon wiedzy, zbiór najlepszych, powszechnie uznanych rozwiązań w dziedzinie zarządzania projektami zebranych i opublikowanych przez członków PMI ${ }^{40}$. Standard ten po raz pierwszy został sformalizowany w 1987 r., a w kolejnych wydaniach nastąpiły jego uzupełnienia i zmiany o charakterze ewolucyjnym. Jest on aktualizowany co cztery lata, najnowsza zaś, piąta edycja pochodzi $\mathrm{z}$ grudnia $2012 \mathrm{r}^{41}$.

Project Management Body of Knowledge jest mocno ukierunkowany na usystematyzowany zestaw konkretnych, sprawdzonych technik i narzędzi zarządczych, opisując pracę jako wynik poszczególnych procesów. Ze względu na nieco większą swobodę implementacji w stosunku do PRINCE2, jest on częściej stosowany przez duże korporacje z sektora prywatnego, a ponadto dostarcza informacji o środowisku leżącym poza obszarem projektu, obejmując na przykład tematykę zagadnień komunikacyjnych, zaopatrzeniowych i międzyludzkich ${ }^{42}$.

International Project Management Association (IPMA) powstała w 1965 r. jako organizacja non-profit zrzeszająca narodowe Stowarzyszenia Project Management, starająca się promować wiedzę z tego zakresu. W porównaniu z innymi metodykami nie definiuje ona procesów i technik zarządzania projektami, lecz wskazuje na konkretne kompetencje, zawarte w trzech obszarach, którymi powinni cechować się kierownicy projektu. Pierwszy $\mathrm{z}$ nich to kompetencje techniczne określane mianem twardych, którego elementy stanowią sedno całego zarządzania projektami i są związane $\mathrm{z}$ tworzeniem produktów projektu. Project menager powinien więc umiejętnie radzić sobie $\mathrm{z}$ motywowaniem, przewodzeniem, negocjacjami, itp. (kompetencje behawioralne), tak aby łatwo mógł funkcjonować w ramach organizacji realizującej określone projekty (kompetencje kontekstowe).

W przeciwieństwie do pozostałych podejść, IPMA proponuje raczej wytyczne niż ścisłą metodykę ${ }^{43}$. Opiera się zatem w dużej mierze na dobrych praktykach i bardzo elastycznym dostosowywaniu rozwiązań do potrzeb konkretnego podmiotu, a nawet warunków prowadzenia określonego typu przedsięwzięć. Otwiera to drogę do wykorzystywania także dorobku innych podejść, na przykład PRINCE2. Cechą charakterystyczną tego podejścia jest także orientacja na techniki definiowania, planowania i controllingu projektu. Powiązane są one z liniowo zdefiniowanym przebiegiem cyklu życia projektu, obejmującym fazę wstępną (inicjacja), fazę planistyczną, realizacyjną oraz zamknięcia ${ }^{44}$. Połączenie wiedzy na temat technik zarządzania $\mathrm{z}$ wiedzą kontekstową i kompetencjami behawioralnymi pozwala na stworzenie czterostopniowego cyklu certyfikacji, pozwalającego rozwijać się od poziomu członka zespołu projektowego do dyrektora zarządzającego dużą firmą, zorientowaną projektowo.

\footnotetext{
${ }^{39}$ PMI, A Guide to the Project Management Body of Knowledge (PMBOK® Guide), wyd. 5, Project Management Institute, Pennsylvania 2013.

${ }^{40} \mathrm{~W}$ Stanach Zjednoczonych PMBoK Guide został zatwierdzony przez American National Standards Institute jako narodowy standard w obszarze zarządzania projektami.

${ }^{41}$ K. Kozioł-Nadolna, op. cit., s. 163 - 164.

${ }^{42}$ A. Koszlajda, Zarzadzanie projektami IT. Przewodnik po metodykach, Helion, Gliwice, s. 31.

${ }^{43}$ IPMA, IPMA Organizational Competence Baseline - The standard for moving organizations forward, IPMA, Zurich, 2013.

${ }^{44}$ Więcej: B. Dałkowski, L. Staśto, M. Zalewski, Polskie Wytyczne Kompetencji IPMA, wersja 3.0, Stowarzyszenie Project Management Polska 2009.
} 
SCRUM to obecnie jedna z najczęściej spotykanych i wykorzystywanych metodyk zwinnego wytwarzania produktów oraz prowadzenia projektów innowacyjnych, wykorzystywana głównie w przedsięwzięciach o nieznanym lub wysokim stopniu niepewności. Opiera się ona na zarządzaniu zmianą, koncentrując się przy tym na ciągłych, twardych negocjacjach pomiędzy graczami, a mianowicie użytkownikiem maksymalnie możliwego elastycznego systemu informatycznego i zespołem projektowym. Nazwa „scrum”, oznacza w języku polskim młyn, nawiązuje do sytuacji występującej podczas gry w rugby. Jej pomysłodawcami są Japończycy Hirotaka Takeuchi i Ikujiro Nonaka, którzy \ w artykule „The New New Product Development Game”, który ukazał się w 1986 r. w „Harvard Business Review", przedstawili ogólne założenia tej metodyki, a jej sformalizowania w 1995 r. dokonał Ken Schwaber ${ }^{45}$.

Cechą charakterystyczną SCRUM jest stosunkowo generyczny charakter, wobec czego nadaje się ono jako zorientowana zarządczo rama dla innych, silniej zorientowanych technicznie praktyk. Metodyka ta promuje nie tylko adaptacyjność, ale także iteracyjnoprzyrostowy proces tworzenia produktu - wartość dodana projektu powstaje w wyniku zastosowania w kolejnych iteracjach faz cyklu życia systemu określonych narzędzi, przeciwdziałających potencjalnemu ryzyku realizacyjnemu, wynikających z wypracowanych dobrych praktyk dla małych i średnich, ale za to złożonych projektów ${ }^{46}$.

\section{PORÓWNANIE PODSTAWOWYCH PODEJŚĆ DO PROJEKTÓW POD WZGLĘDEM SZKOLEŃ I CERTYFIKACJI}

Współcześnie, ze względu na profesjonalizację zarządzania projektami menedżerowie, oprócz wieloletniej praktyki, powinni mieć również odpowiednią wiedzę. Pomocne w jej zdobyciu mogą być szkolenia z zarządzania projektami, kończące się uzyskaniem odpowiedniej certyfikacji ${ }^{47}$. Certyfikaty międzynarodowe są $\mathrm{z}$ jednej strony uznaną formą potwierdzenia posiadanych kwalifikacji i umiejętności zawodowych ich posiadacza, z drugiej natomiast stanowią swego rodzaju przepustkę, dającą dostęp do większej liczby zleceń i większych zarobków. Podnoszą one nie tylko pewność siebie i własnej wartości na rynku pracy, ale także zwiększają wiarygodność w oczach potencjalnych pracodawców. Ich uzyskanie wiąże się z koniecznością spełnienia różnych wymagań dotyczących wiedzy i doświadczenia oraz z poniesieniem, często bardzo wysokich, kosztów ${ }^{48}$. Wymagania warunkujące otrzymanie certyfikatu określają autoryzujące go organizacje i mogą one obejmować udział w konkretnych szkoleniach, zdanie jednego lub kilku egzaminów, a niekiedy dodatkowo udokumentowanie praktyki zawodowej w określonej dziedzinie, a nawet wykonanie projektu studialnego ${ }^{49}$. Najbardziej znanymi firmami, które udzielają certyfikacji z zakresu zarządzania projektami, są: PMI ${ }^{50}$, IPMA ${ }^{51}$, APM Group oraz Scrum Alliance ${ }^{52}$. Stosowane przez nie zasady certyfikacji omówiono w tabeli 2.

\footnotetext{
${ }^{45} \mathrm{http}: / /$ scrum.hypersquare.com/podstawy-scruma.html (dostęp: 30.03.2015)

${ }^{46}$ W. Chmielarz, op. cit., s. 35.

${ }^{47} \mathrm{http}: / /$ www.szkolenia.com.pl/index/artykul/29 (dostęp: 5.04.2015)

$48 \mathrm{http}: / /$ www.4pm.pl/artykuly/warunki-uzyskania-i-koszty-certyfikatow-dla-menedzerow-projektow (dostęp: 5.04. 2015)

${ }^{49} \mathrm{http}: / /$ www.altkomakademia.pl/sciezki (dostęp: 5.04.2015)

${ }^{50}$ Certyfikaty CAPM, PMP oraz PgMP występują na trzech poziomach, bez konieczności przechodzenia kolejno wszystkich. Są one niezależne, a zdający sami wybierają, o jaki certyfikat chcą i mogą się ubiegać. Inne certyfikaty oferowane przez PMI to: PfMP (Portfolio Management Professional), PMI-ACP (PMI Agile Certified
} 
Tabela 2. Porównanie najpopularniejszych certyfikatów z zakresu zarządzania projektami.

\begin{tabular}{|c|c|c|c|c|}
\hline Parametry & \multicolumn{4}{|c|}{ Rodzaj certyfikatu } \\
\hline Wystawca & \multicolumn{4}{|c|}{ APM Group } \\
\hline Nazwa certyfikatu & \multicolumn{2}{|c|}{ PRINCE2 Foundation } & \multicolumn{2}{|c|}{ PRINCE2 Practitioner } \\
\hline $\begin{array}{l}\text { Szczebel kariery / } \\
\text { wymagania kwali- } \\
\text { fikacyjne }\end{array}$ & \multicolumn{2}{|c|}{$\begin{array}{l}\text { Wiedza na temat metodyki bez koniecz- } \\
\text { ności praktycznego jej stosowania }\end{array}$} & \multicolumn{2}{|c|}{$\begin{array}{l}\text { Menedżerowie projektów zdolni do } \\
\text { rozwiązywania problemów zarządczych } \\
\text { oraz certyfikat Prince2 Foundation }\end{array}$} \\
\hline Egzamin & \multicolumn{2}{|l|}{ Tak } & \multicolumn{2}{|c|}{ Tak } \\
\hline $\begin{array}{l}\text { Liczba/rodzaj/ } \\
\text { forma pytań }\end{array}$ & \multicolumn{2}{|c|}{$\begin{array}{l}75 \text { testowych jednokrotnego wyboru } \\
\text { w języku polskim lub angielskim }\end{array}$} & \multicolumn{2}{|c|}{$\begin{array}{c}9 \text { testowych wielokrotnego wyboru ułożo- } \\
\text { nych na podstawie case study } \\
\text { w jezyku polskim lub angielskim }\end{array}$} \\
\hline Czas trwania & \multicolumn{2}{|l|}{1 godzina } & \multicolumn{2}{|c|}{3 godziny } \\
\hline Poziom trudności & \multicolumn{2}{|l|}{ Sredni } & \multicolumn{2}{|c|}{ Trudny } \\
\hline Zakres wiedzy & \multicolumn{2}{|c|}{$\begin{array}{l}\text { Wiedza na temat metodyki oraz znajo- } \\
\text { mość Prince } 2 \text { Manual }\end{array}$} & \multicolumn{2}{|c|}{ Znajomość Prince2 Manual } \\
\hline Doświadczenie & \multicolumn{2}{|c|}{$\begin{array}{c}\text { Brak wymagań względem wyjściowej } \\
\text { wiedzy lub doświadczenia }\end{array}$} & \multicolumn{2}{|c|}{ Brak wymagań } \\
\hline Wiek kandydata & \multicolumn{2}{|c|}{ Brak ograniczeń } & \multicolumn{2}{|c|}{ Brak ograniczeń } \\
\hline $\begin{array}{l}\text { Ważność certyfi- } \\
\text { katu / recertyfika- } \\
\text { cja certyfikatu }\end{array}$ & \multicolumn{2}{|c|}{$\begin{array}{c}\text { Przyznawany dożywotnio, bez koniecz- } \\
\text { ności re certyfikacji }\end{array}$} & \multicolumn{2}{|c|}{$\begin{array}{c}5 \text { lat - odnowienie na podstawie egzaminu } \\
\text { testowego wielokrotnego wyboru złożo- } \\
\text { nego z trzech obszarów pytań na bazie } \\
\text { case study }\end{array}$} \\
\hline Koszt & 220 funtów (w Polsce okołc & 600 PLN) & 410 funtów & Polsce około 2200 PLN) \\
\hline Wystawca & \multicolumn{4}{|c|}{ Project Management Institute (PMI) } \\
\hline Nazwa certyfikatu & $\begin{array}{c}\text { CAPM } \\
\text { (Certified Associate } \\
\text { in Project Management) }\end{array}$ & $\begin{array}{r}\text { (Project } \\
\text { Prof }\end{array}$ & $\begin{array}{l}\text { MP } \\
\text { lanagement } \\
\text { sional) }\end{array}$ & $\begin{array}{c}\text { PgMP } \\
\text { (Program Management } \\
\text { Professional) }\end{array}$ \\
\hline $\begin{array}{l}\text { Szczebel kariery / } \\
\text { wymagania } \\
\text { kwalifikacyjne }\end{array}$ & $\begin{array}{l}\text { Osoby stawiające pierw- } \\
\text { sze kroki w zarządzaniu } \\
\text { projektami, początkujący } \\
\text { kierownicy, członkowie } \\
\text { zespołów projektowych }\end{array}$ & $\begin{array}{r}\text { Kierown } \\
\text { posiada } \\
\text { licencjata } \\
\text { ekwiwale } \\
\text { we }\end{array}$ & $\begin{array}{l}\text { y projektów } \\
\text { cy dyplom } \\
\text { magistra lub } \\
\text { ny tytuł uni- } \\
\text { ytecki }\end{array}$ & $\begin{array}{l}\text { Menedżerowie progra- } \\
\text { mów, posiadający bogate } \\
\text { doświadczenie } \\
\text { i umiejętność zarządzania } \\
\text { wieloma projektami }\end{array}$ \\
\hline Egzamin & Tak & & ak & Tak \\
\hline $\begin{array}{l}\text { Liczba/rodzaj } \\
\text { orma pytań }\end{array}$ & $\begin{array}{c}150 \text { testowych w języku } \\
\text { angielskim }\end{array}$ & $\begin{array}{r}200 \text { testov } \\
\text { ang }\end{array}$ & $\begin{array}{l}\text { ch w języku } \\
\text { elskim }\end{array}$ & $\begin{array}{l}170 \text { testowych w języku } \\
\text { angielskim }\end{array}$ \\
\hline Czas trwania & 3 godziny & & dziny & 4 godziny \\
\hline Poziom trudności & Sredni & & Idny & Trudny \\
\hline Zakres wiedzy & Znajomość PMBoK Guide & $\begin{array}{r}\text { Wiedza og } \\
\text { zarządzan } \\
\text { PMBoK } \\
\text { kodeksu e }\end{array}$ & $\begin{array}{l}\text { lna z zakresu } \\
\text {, znajomość } \\
\text { Guide oraz } \\
\text { cznego PMI }\end{array}$ & $\begin{array}{l}\text { Znajomość PMBoK } \\
\text { Guide oraz The Standard } \\
\text { for Program Management }\end{array}$ \\
\hline Doświadczenie & $\begin{array}{c}1500 \text { godzin doświadcze- } \\
\text { nia (czyli } \\
\text { w praktyce około rok) } \\
\text { w zespole projektowym } \\
\text { lub odbyte szkolenie } \\
\text { w wymiarze } 23 \text { godzin }\end{array}$ & $\begin{array}{l}4.500 \text { go } \\
\text { lata) do } \\
\text { oraz minin } \\
\text { szkoleń w } \\
\text { dzania p } \\
\text { osób z u }\end{array}$ & $\begin{array}{l}\text { zin (około } 3 \\
\text { viadczenia } \\
\text { am } 35 \text { godzin } \\
\text { akresie zarzą- } \\
\text { jektami dla } \\
\text { ższym wy- }\end{array}$ & $\begin{array}{l}\text { Dyplom licencjata oraz co } \\
\text { najmniej } 6.000 \text { godzin } \\
\text { (około } 4 \text { lata) doświad- } \\
\text { czenia } \\
\text { w zarządzaniu projektami } \\
\text { i programami }\end{array}$ \\
\hline
\end{tabular}

Practitioner), PMI-PBA (PMI Professional in Business Analysis), PMI-SP (PMI Scheduling Professional), PMI-RMP (PMI Risk Management Professional). http://www.pmi.org/ certification.aspx (dostęp: 8.04.2015).

${ }^{51}$ Certyfikaty IPMA zakładają stopniowe przechodzenie przez cztery kolejne poziomy od D do A.

${ }^{52}$ Scrum Alliance oferuje trzy stopnie certyfikatów - certyfikaty I stopnia: CSM, CSPO i CSD, II stopnia: CSP (Certified Scrum Professional) oraz III stopnia: CST (Certified Scrum Trainer) i CSC (Certified Scrum Coach). http://www.4pm.pl/artykuly/warunki-uzyskania-i-koszty-certyfikatow-dla-menedzerow-projektow (dostęp: 15.04.2105). 


\begin{tabular}{|c|c|c|c|c|c|c|}
\hline Parametry & \multicolumn{6}{|c|}{ Rodzaj certyfikatu } \\
\hline & \multicolumn{2}{|c|}{$\begin{array}{c}\text { formalnej edukacji } \\
\text { w obszarze zarządzania } \\
\text { projektami }\end{array}$} & \multicolumn{2}{|c|}{$\begin{array}{c}\text { kształceniem; } \\
\text { dodatkowe } 3.000 \text { godzin } \\
\text { doświadczenia dla osób } \\
\text { bez dyplomu ukończenia } \\
\text { uczelni wyższej }\end{array}$} & & \\
\hline Wiek kandydata & \multicolumn{2}{|c|}{ Brak ograniczeń } & \multicolumn{2}{|c|}{ Brak ograniczeń } & \multicolumn{2}{|r|}{ Brak ograniczeń } \\
\hline $\begin{array}{l}\text { Ważność certyfi- } \\
\text { katu / recertyfika- } \\
\text { cja }\end{array}$ & \multicolumn{2}{|c|}{$\begin{array}{l}5 \text { lat - odnowienie na } \\
\text { podstawie ponownego } \\
\text { Egzaminu }\end{array}$} & \multicolumn{2}{|c|}{$\begin{array}{c}3 \text { lata - wymaga się } \\
\text { recertyfikacji poprzez } \\
\text { Zebranie } 60 \text { PDU } 53 \\
\text { w ciągu } 3 \text { lat od zdania } \\
\text { egzaminu w ramach } \\
\text { zatwierdzonej przez PMI } \\
\text { aktywności lub powtórny } \\
\text { egzamin }\end{array}$} & \multicolumn{2}{|c|}{$\begin{array}{c}3 \text { lata - należy zebrać } 60 \\
\text { PDU w cyklu trzyletnim } \\
\text { W ramach zatwierdzonej } \\
\text { przez PMI aktywności lub } \\
\text { zdać egzamin recertyfiku- } \\
\text { jący }\end{array}$} \\
\hline Koszt & \multicolumn{2}{|c|}{$\begin{array}{l}250 \text { euro (300 USD); } \\
185 \text { euro (225 USD) dla } \\
\text { członków PMI }\end{array}$} & \multicolumn{2}{|c|}{$\begin{array}{c}465 \text { euro (555 USD); } \\
340 \text { euro (zniżka dla } \\
\text { członków PMI) }\end{array}$} & \multicolumn{2}{|c|}{$\begin{array}{c}1500 \text { euro (1.800 USD); } \\
1250 \text { euro dla stowarzy- } \\
\text { szonych w PMI }\end{array}$} \\
\hline Wystawca & \multicolumn{6}{|c|}{ IPMA (International Project Management Association) } \\
\hline Nazwa certyfikatu & $\begin{array}{c}\text { IPMA-D } \\
\text { (Certified Pro- } \\
\text { ject Management } \\
\text { Associate })\end{array}$ & $(\mathrm{Ce})$ & $\begin{array}{l}\text { MA-C } \\
\text { ied Project } \\
\text { nager) }\end{array}$ & $\begin{array}{r}\text { IPMA- } \\
\text { (Certified } S \\
\text { Project } M a\end{array}$ & & $\begin{array}{c}\text { IPMA-A } \\
\text { (Certified Projects } \\
\text { Director) }\end{array}$ \\
\hline $\begin{array}{l}\text { Szczebel kariery / } \\
\text { wymagania kwali- } \\
\text { fikacyjne }\end{array}$ & $\begin{array}{c}\text { Członkowie } \\
\text { zespołów projek- } \\
\text { towych nieposia- } \\
\text { dający praktycz- } \\
\text { nego doświad- } \\
\text { czenia, } \\
\text { a jedynie wiedzę } \\
\text { teoretyczną } \\
\text { z zakresu zarzą- } \\
\text { dzania projekta- } \\
\text { mi }\end{array}$ & $\begin{array}{l}\text { Kierc } \\
\text { tów } \\
\text { cy a } \\
\text { ce } \\
\text { refer } \\
\text { zow }\end{array}$ & $\begin{array}{l}\text { hicy projek- } \\
\text { edstawiają- } \\
\text { Isz samoo- } \\
\text { oraz listę } \\
\text { yjną zreali- } \\
\text { ch projek- } \\
\text { tów }\end{array}$ & $\begin{array}{r}\text { Menedżer } \\
\text { dużych, złoz } \\
\text { przedsięw } \\
\text { (wymagania } \\
\text { poziomie } \\
\text { raport z pro } \\
\text { oraz udział } \\
\text { godzinnej r } \\
\text { wie na te } \\
\text { zaproponow } \\
\text { w nim rozw }\end{array}$ & $\begin{array}{l}\text { ie } \\
\text { ych } \\
\text { ć } \\
\text { k na } \\
\text { ktu } \\
1,5- \\
\text { no- } \\
\text { t } \\
\text { ych } \\
\text { ań) }\end{array}$ & $\begin{array}{l}\text { Dyrektorzy projek- } \\
\text { tów wykazujący } \\
\text { się kompetencjami } \\
\text { z zakresu zarzą- } \\
\text { dzania programami } \\
\text { i portfelami pro- } \\
\text { jektów }\end{array}$ \\
\hline Egzamin & Tak & & Tak & $\begin{array}{l}\text { Często wym } \\
\text { jeśli brak IP }\end{array}$ & & $\mathrm{Nie}$ \\
\hline $\begin{array}{l}\text { Liczba/rodzaj } \\
\text { forma pytań }\end{array}$ & $\begin{array}{l}\text { Zależy od kraju } \\
\text { (pytania za- } \\
\text { mknięte, otwarte, } \\
\text { zadania oparte na } \\
\text { studium przy- } \\
\text { padku oraz } \\
\text { obliczenia) }\end{array}$ & $\begin{array}{r}\text { Zal } \\
\text { (pyt } \\
\mathrm{pr} \\
\text { war } \\
\text { towe } \\
\mathrm{sp} \\
\mathrm{i} \mathrm{p} \\
\text { osobc } \\
\mathrm{w} \\
\mathrm{p}\end{array}$ & $\begin{array}{l}\text { y od kraju } \\
\text { a i zadania } \\
\text { lemowe, } \\
\text { aty projek- } \\
\text { az rozmowa } \\
\text { vdzająca } \\
\text { iedzę } \\
\text { yspozycje } \\
\text { e kandydata } \\
\text { ządzaniu } \\
\text { ektami) }\end{array}$ & Zależy od & & Nie dotyczy \\
\hline Czas trwania & $\begin{array}{l}\text { Zależy od kraju, } \\
\text { najczęściej } \\
\text { dwuczęściowy, } \\
\text { tzygodzinny }\end{array}$ & $\begin{array}{l}\text { Naj } \\
\text { częśs } \\
\text { dzi } \\
\text { egz } \\
\text { dni }\end{array}$ & $\begin{array}{l}\text { Ściej dwu- } \\
\text { wy (trzygo- } \\
\text { y pisemny } \\
\text { in i jedno- } \\
\text { y warsztat } \\
\end{array}$ & $\begin{array}{r}\text { Dwuczęśc } \\
(\text { dwugodz } \\
\text { pisemny eg. } \\
\text { jednodnic } \\
\text { warsztat pro }\end{array}$ & & Nie dotyczy \\
\hline
\end{tabular}

53 PDU (Professional Development Units) - umowna jednostka określająca stopień zaangażowania osoby posiadającej określony certyfikat w proces samodoskonalenia i rozwoju swoich umiejętności w określonym kierunku. http://www.hdi.pl/index.php?page=pytania-i-odpowiedzi (dostęp: 10.04.2105). 


\begin{tabular}{|c|c|c|c|c|c|c|}
\hline Parametry & \multicolumn{6}{|c|}{ Rodzaj certyfikatu } \\
\hline & & \multicolumn{2}{|c|}{$\begin{array}{l}\text { projektowy) oraz } \\
\text { godzina rozmowy } \\
\text { weryfikująca } \\
\text { wiedzę, doświad- } \\
\text { czenie } \\
\text { i predyspozycje } \\
\text { kandydata } \\
\end{array}$} & \multicolumn{2}{|c|}{$\begin{array}{l}\text { wy) oraz godzinna } \\
\text { rozmowa }\end{array}$} & \\
\hline Poziom trudności & Średni & \multicolumn{2}{|c|}{ Trudny } & \multicolumn{2}{|l|}{ Trudny } & Nie dotyczy \\
\hline Zakres wiedzy & $\begin{array}{l}\text { Znajomość } \\
\text { IPMA Compe- } \\
\text { tence Baseline }\end{array}$ & \multicolumn{2}{|c|}{$\begin{array}{c}\text { Znajomość } \\
\text { IPMA Competence } \\
\text { Baseline }\end{array}$} & \multicolumn{2}{|c|}{$\begin{array}{c}\text { Znajomość } \\
\text { IPMA Competence } \\
\text { Baseline }\end{array}$} & $\begin{array}{c}\text { Znajomość } \\
\text { IPMA Competence } \\
\text { Baseline }\end{array}$ \\
\hline Doświadczenie & $\begin{array}{l}\text { Rok niekoniecz- } \\
\text { nie } \\
\text { w projekcie }\end{array}$ & \multicolumn{2}{|c|}{$\begin{array}{l}\text { Minimum } 3 \text { lata } \\
\text { w kierowaniu } \\
\text { projektami } \\
\text { o ograniczonej } \\
\text { złożoności }\end{array}$} & \multicolumn{2}{|c|}{$\begin{array}{l}5 \text { lat w zarządzaniu } \\
\text { projektami, w tym } \\
\text { co najmniej } 3 \text { lata } \\
\text { na stanowisku } \\
\text { kierowniczym }\end{array}$} & $\begin{array}{l}5 \text { lat w zarządzaniu } \\
\text { portfelami, pro- } \\
\text { gramami lub } \\
\text { jednoczesnym } \\
\text { zarządzaniu wie- } \\
\text { loma projektami } \\
\end{array}$ \\
\hline Wiek kandydata & 20 lat & \multicolumn{2}{|c|}{25 lat } & \multicolumn{2}{|l|}{30 lat } & 35 lat \\
\hline $\begin{array}{l}\text { Ważność certyfi- } \\
\text { katu / recertyfika- } \\
\text { cja }\end{array}$ & Bezterminowo & \multicolumn{2}{|c|}{$\begin{array}{l}5 \text { lat - odnowienie } \\
\text { na podstawie } \\
\text { wniosku o przedłu- } \\
\text { żenie certyfikatu }\end{array}$} & \multicolumn{2}{|c|}{$\begin{array}{l}5 \text { lat - odnowienie } \\
\text { na podstawie } \\
\text { wniosku o przedłu- } \\
\text { żenie certyfikatu }\end{array}$} & $\begin{array}{l}5 \text { lat - odnowienie } \\
\text { na podstawie } \\
\text { wniosku o prze- } \\
\text { dłużenie certyfika- } \\
\text { tu } \\
\end{array}$ \\
\hline Koszt & $\begin{array}{l}\text { Zależy od kraju - } \\
\text { w Polsce } 1000 \\
\text { PLN; } \\
\text { recertyfikacja - } \\
\text { 300 PLN }\end{array}$ & \multicolumn{2}{|c|}{$\begin{array}{l}\text { Zależy od kraju - } \\
\text { w Polsce } 6000 \\
\text { PLN; } \\
\text { recertyfikacja - } \\
1000 \text { PLN }\end{array}$} & \multicolumn{2}{|c|}{$\begin{array}{c}\text { Zależy od kraju - } \\
\text { w Polsce } 8000 \text { PLN } \\
\text { lub dopłata } 3000 \\
\text { PLN do poziomu } \\
\text { C; } \\
\text { recertyfikacja - } \\
1000 \text { PLN }\end{array}$} & $\begin{array}{l}\text { Zależy od kraju - } \\
\text { w Polsce } 10000 \\
\text { PLN lub dopłata } \\
3000 \text { PLN do } \\
\text { poziomu B; } \\
\text { recertyfikacja - } \\
1000 \text { PLN }\end{array}$ \\
\hline Wystawca & \multicolumn{6}{|c|}{ Scrum Alliance } \\
\hline Nazwa certyfikatu & \multicolumn{2}{|c|}{$\begin{array}{c}\text { CSM } \\
\text { (Certified Scrum Master) }\end{array}$} & \multicolumn{2}{|c|}{$\begin{array}{c}\text { CSD } \\
\text { (Certified Scrum Develop- } \\
\text { er) }\end{array}$} & \multicolumn{2}{|c|}{$\begin{array}{c}\text { CSPO } \\
\text { (Certified Scrum Product } \\
\text { Owner) }\end{array}$} \\
\hline $\begin{array}{l}\text { Szczebel kariery / } \\
\text { wymagania } \\
\text { kwalifikacyjne }\end{array}$ & \multicolumn{2}{|c|}{$\begin{array}{l}\text { Członkowie i kierownicy } \\
\text { zespołów scrumowych }\end{array}$} & \multicolumn{2}{|c|}{$\begin{array}{l}\text { Osoby będące bezpośred- } \\
\text { nio zaangażowane w } \\
\text { rozwój oprogramowania }\end{array}$} & \multicolumn{2}{|c|}{$\begin{array}{c}\text { Analitycy biznesowi oraz } \\
\text { kadra zarządzająca, } \\
\text { zwłaszcza kierownicy } \\
\text { produktów i zespołów }\end{array}$} \\
\hline Egzamin & \multicolumn{2}{|c|}{ Tak } & \multicolumn{2}{|c|}{ Nie } & \\
\hline $\begin{array}{l}\text { Liczba/rodzaj } \\
\text { forma pytań }\end{array}$ & \multicolumn{2}{|c|}{$\begin{array}{c}35 \text { testowych w języku } \\
\text { angielskim }\end{array}$} & \multicolumn{2}{|c|}{ Nie dotyczy } & \multicolumn{2}{|r|}{ Nie dotyczy } \\
\hline Czas trwania & \multicolumn{2}{|c|}{ Nieograniczony } & \multicolumn{2}{|c|}{ Nie dotyczy } & \multirow{2}{*}{\multicolumn{2}{|c|}{$\frac{\text { Nie dotyczy }}{\text { Nie dotyczy }}$}} \\
\hline Poziom trudności & \multicolumn{2}{|c|}{ Łatwy } & \multicolumn{2}{|c|}{ Nie dotyczy } & \multirow{2}{*}{\multicolumn{2}{|c|}{$\begin{array}{c}\text { Nie dotyczy } \\
\text { Znajomość podstawowej } \\
\text { wiedzy z zakresu zarzą- } \\
\text { dzania projektami oraz } \\
\text { głównych założeń metody } \\
\text { Scrum (Scrum Guide) }\end{array}$}} \\
\hline $\begin{array}{c}\text { Zakres wiedzy / } \\
\text { kluczowa publika- } \\
\text { cja }\end{array}$ & \multicolumn{2}{|c|}{$\begin{array}{l}\text { Znajomość podstawowej } \\
\text { wiedzy z zakresu zarzą- } \\
\text { dzania projektami oraz } \\
\text { głównych założeń metody } \\
\text { Scrum (Scrum Guide) }\end{array}$} & \multicolumn{2}{|c|}{$\begin{array}{c}\text { Znajomość wiedzy } \\
\text { z zakresu zarządzania } \\
\text { projektami oraz podsta- } \\
\text { wowych założeń metodyki } \\
\text { Scrum (Scrum Guide) }\end{array}$} & & \\
\hline Doświadczenie & $\begin{array}{l}\text { Ukończone dwudn } \\
\text { szkolenia Scrum I }\end{array}$ & $\begin{array}{l}\text { oster } \\
\text { astego }\end{array}$ & $\begin{array}{r}\text { Udział w p } \\
\text { szkoleniu a } \\
\text { przez } S c r t \\
\text { dni szkole }\end{array}$ & $\begin{array}{l}\text { ciodniowym } \\
\text { redytowanym } \\
\text { Alliance ( } 3 \\
\text { e techniczne) }\end{array}$ & $\begin{array}{l}\text { Uko } \\
\text { go s } \\
\text { negc }\end{array}$ & $\begin{array}{l}\text { hczenie dwudniowe- } \\
\text { kolenia akredytowa- } \\
\text { przez Scrum Allian- } \\
\text { ce }\end{array}$ \\
\hline Wiek kandydata & Brak ogranicz & & Brak & raniczeń & & Brak ograniczeń \\
\hline $\begin{array}{l}\text { Ważność certyfi- } \\
\text { katu / recertyfika- }\end{array}$ & $\begin{array}{l}2 \text { lata - po tym o } \\
\text { niezbędne jest jeg }\end{array}$ & $\begin{array}{l}\text { esie } \\
\text { odno- }\end{array}$ & $\begin{array}{l}2 \text { lata }-p \\
\text { niezbędne }\end{array}$ & $\begin{array}{l}\text { tym okresie } \\
\text { st jego odno- }\end{array}$ & & $\begin{array}{l}\text { ta - po tym okresie } \\
\text { będne jest jego od- }\end{array}$ \\
\hline
\end{tabular}




\begin{tabular}{|c|c|c|c|}
\hline Parametry & \multicolumn{3}{|c|}{ Rodzaj certyfikatu } \\
\hline cja & $\begin{array}{c}\text { wienie i opłacenie stawki } \\
\text { członkowskiej (150 USD) }\end{array}$ & $\begin{array}{c}\text { wienie i opłacenie stawki } \\
\text { członkowskiej (150 USD) }\end{array}$ & $\begin{array}{c}\text { nowienie i opłacenie } \\
\text { stawki członkowskiej } \\
\text { (150 USD) }\end{array}$ \\
\hline
\end{tabular}

\begin{tabular}{|c|c|c|c|}
\hline Koszt & W Polsce około 4000 PLN & W Polsce około 4000 PLN & $\begin{array}{c}\text { W Polsce około 4000 } \\
\text { PLN }\end{array}$ \\
Źródło: Opracowanie własne na podstawie: & http://pmit.pl/wordpress/wp-content/uploads/2009/02/pm\%20 \\
certificates\%20 full\%20pl.htm (dostęp: 11.04.2015); http://www.pmi.org/Certification/Project-Management- \\
Professional-PMP.aspx (dostęp: 10.04. 2015), http://karieraplus.pl/artykuly/certyfikaty-w-zarządzaniu \\
(12.04.2015); http://www.poddrzewem.pl/do-poczytania/ certyfikacja-scrum-wedlug-scrum-alliance \\
(10.04.2015); https://www.scrumalliance.org/certifications/Practitioner (dostęp: 13. 04.2015) oraz \\
http://www.klubtrenerow. firma2000.pl/blog/indem.php?id=d8alaeey (dostęp: 10.04.2015).
\end{tabular}

Jak wynika z tabeli 2 ze zdobyciem każdego z analizowanych certyfikatów są związane nie tylko nakłady finansowe, ale również często osobiste wyrzeczenia dotyczące czasu poświęconego na szkolenia i przygotowania do egzaminów. Jedną z fundamentalnych różnic pomiędzy nimi jest fakt, że certyfikaty PMI i IPMA dotyczą zarządzania projektami, te oferowane przez APM zaś wymagają jedynie znajomości metodyki PRINCE2. Dodatkowo certyfikaty IPMA potwierdzają nie tylko posiadaną wiedzę i doświadczenie kandydata, ale także jego kompetencje kierownicze i interpersonalne, kładąc szczególny nacisk na cechy osobowościowe.

\section{WNIOSKI}

Przedstawione porównanie poszczególnych koncepcji i podejść do zarządzania projektami należy traktować jako próbę uporządkowania informacji, niezbędnych dla osób rozwijających kompetencje w zakresie tej metody. Zarówno w poszczególnych przedsiębiorstwach, branżach, jak i w innych dziedzinach rozwija się wiele systemowych rozwiązań, które mają służyć wsparciu realizacji projektów. W większości przypadków dotyczą one zarówno wymiaru ogólno-organizacyjnego, jak i przebiegu projektu (cyklu życia). Warto podkreślić, że poszczególne podejścia różnią się od siebie, a ich stosowanie nie wyklucza czerpania także z innych wartościowych rozwiązań.

Podstawowym problemem w doborze podejścia właściwego dla danej organizacji jest uwzględnienie specyfiki projektu oraz możliwości danej organizacji. Wdrożenia systemów zarządzania projektami nie mogą być zbyt rozbudowane w stosunku do jej możliwości. Należy zatem unikać zbędnych procedur biurokratycznych oraz dodatkowych obciążeń (np. raportowych), związanych $\mathrm{z}$ tworzonym systemem komunikacji projektowej. Warto także zwrócić uwagę na zmianę warunków prowadzenia projektów w tak dynamicznym otoczeniu, z jakim mają do czynienia współczesne organizacje. Tworzy ono bardzo szczególne wymagania realizacyjne, wynikające między innymi z pojawiania się nowych obszarów ryzyka i znacznego wpływu niepewności (czynników, których nie sposób przewidzieć w trakcie planowania projektu). Przebieg nawet projektów infrastrukturalnych coraz trudniej zamyka się więc w ramach podejść liniowych i wymaga uwzględnienia rozwiązań zwinnych. $Z$ kolei rosnące wymagania w zakresie efektywności projektów i minimalizacji kosztów wymagają narzucenie dyscypliny czasowej i finansowej, co jest znacznie trudniejsze w wypadku metodyk miękkich niż podejść tradycyjnych. 
Należy zatem przyjąć, że rozwiązania optymalne dla danego przedsiębiorstwa czy projektu nie zamykają się w ramach jednego podejścia. Warto zatem budować systemy zarządzania projektami oparte raczej na wyodrębnieniu z różnych podejść narzędzi użytecznych dla danych warunków. Szczególnie należy tutaj dążyć do budowania takiego systemu, w którym umiejętnie łączy się reżim projektu zarządzanego liniowo z lekkim i zwinnym podejściem, pozwalającym na szybką reakcję zarówno na zmianę oczekiwań klienta, jak i na powstanie innych istotnych czynników zmieniających często drastycznie warunki prowadzenia projektu.

\section{LITERATURA}

[1] Andersen E.S., Jessen S.A., Project maturity in organisations, "International Journal of Project Management”, 21/6 (2003), s. 457 - 461.

[2] Borowska K., Zastosowanie metody Project Cycle Management w zarzqdzaniu projektami wspótfinansowanymi ze środków unijnych [w:] Heraditas Mercaturae. Księga pamiątkowa dedykowana świętej pamięci profesorowi S. Miklaszewskiemu, red. P. Czubik i Z. Mach, Instytut Multimedialny, Kraków 2012.

[3] Chmielarz W., Kryteria wyboru metod zarzadzania projektami informatycznymi, „Problemy Zarządzania", 38/3 (2012), s. 25 - 40.

[4] Cooke-Davies T., Project management maturity models, [w:] The Wiley guide to managing projects, red. P. Morris, Peter, J.K. Pinto, John Wiley \& Sons, Hoboken, NJ, 2004, s. 1234 1255.

[5] Dałkowski B., Staśto L., Zalewski M., Polskie Wytyczne Kompetencji IPMA, wersja 3.0, Stowarzyszenie Project Management Polska 2009.

[6] Frączkowski K., Zarządzanie projektem informatycznym, Oficyna Wydawnicza Politechniki Wrocławskiej, Wrocław 2003.

[7] Habela P., Metodyki zarzadzania projektem, PJWSTK, Warszawa 2011.

[8] IPMA, IPMA Organizational Competence Baseline - The standard for moving organizations forward, IPMA, Zurich, 2013.

[9] Kopczyński T., Rola i kompetencje kierownika projektu w zwinnym zarzqdzaniu projektami na tle tradycyjnego podejścia do zarządzania projektami, „Studia Oeconomica Posnaniensia” 270/9 (2014).

[10] Koszlajda A., Zarzadzanie projektami IT. Przewodnik po metodykach, Helion, Gliwice 2010.

[11] Kozarkiewicz A., Zarzadzanie portfelami projektów, PWN, Warszawa 2012.

[12] Kozioł-Nadolna K., Metodyki zarzadzania projektami, [w:] Zarzadzanie projektami w organizacji, red. K. Janasz i J. Wiśniewska, Difin, Warszawa 2014.

[13] Kwak Y.H., A brief history of Project Management, [w:] The story of managing projects, red. G. Carayannis, Y.H. Kwak, FT. Anbari, Quorum Books, USA 2003.

[14] Lampel J., Pushkar P.J., Models of project orientation in multiproject organizations, [w:] The Wiley guide to managing projects, red. P. Morris, J.K. Pinto, John Wiley \& Sons, Hoboken, NJ, 2004, s. 223-236.

[15] Małyszek E., Zarządzanie projektami (Project Management) w mikro i matych przedsiębiorstwach, http://www.lbs.pl/projekt/dobrepraktyki2011/files/ artykuly/art._ Malyszek.pdf.

[16] Miśtal Z., Zarzadzanie projektami w muzeum na przykładzie Muzeum Historycznego Miasta Krakowa, [w:] Zarzqdzanie w kulturze, t. 10, red. E. Orzechowski i K. Plebańczyk, Wydawnictwo Uniwersytetu Jagiellońskiego, Kraków 2009.

[17] Munns A.K., Bjeirmi B.F., The role of project management in achieving project success, „International Journal of Project Management”, 14/2 (1996), s. 81 - 87.

[18] OGC, Managing Successful Projects with PRINCE2 ${ }^{T M}$, Office of Government Commerce, TSO, London 2009. 
[19] PMI, A Guide to the Project Management Body of Knowledge (PMBOK® Guide), wyd. 5, Project Management Institute Pennsylvania 2013.

[20] Rodney T.J., Müller R., On the nature of the project as a temporary organization, "International Journal of Project Management", 21/1 (2003), s. 1 - 8.

[21] Seymour T., Hussein S., The History of Project Management," International Journal of Management \& Information Systems", 18/4 (2013), s. 233 - 240.

[22] Strojny J., Zarzadzanie projektami innowacyjnymi, Politechnika Rzeszowska, Rzeszów 2012.

[23] Wodecka-Hyjek A., Metodyka PRINCE2 w zarzadzaniu realizacja projektów, [w:] Nurt metodologiczny w naukach o zarzadzaniu. 50 lat pracy naukowej prof. zw. dr hab. Zofii Mikołaj$c z y k$, red. W. Błaszczyk, I. Bednarska-Wnuk, P. Kuźbik, Wydawnicto Uniwersytetu Łódzkiego, Łódź 2010

[24] Wyrozębski P., Elastyczne podejście do zarządzania projektami [w:] Problemy wspótczesnej praktyki zarzadzania, red. S. Lachiewicz i M. Matejun, Wydawnictwo Politechniki Łódzkiej, Łódź 2007, s. 151-152.

[25] Wyrozębski P., Zarzq̨dzanie wiedzq, Difin, Warszawa 2014.

\section{ŹRÓDŁA INTERNETOWE}

[1] http://akson.sgh.waw.pl/ darry/PM/Texts/introduction.html

[2] http://karieraplus.pl/artykuly/certyfikaty-w-zarządzaniu

[3] http://pmit.pl/wordpress/wp-content/uploads/2009/02/pm\%20certificates $\% 20$ full $\% 20$ pl.htm.

[4] http://scrum.hypersquare.com/podstawy-scruma.html

[5] http://support.office.com/pl-pl/article/Historia-zarz\%C4\%85dzania-projektami-a2e0b 717094b-4d1e-87 8a-fcd0978891cd

[6] http://www.4pm.pl/artykuly/metodyka-zarządzania-projektami-prince2

[7] http://www.4pm.pl/artykuly/przyjrzyjmy-sie-tradycyjnym-projektom

[8] http://www.4pm.pl/artykuly/warunki-uzyskania-i-koszty-certyfikatow-dla-menedzero w-projektow

[9] http://www.altkomakademia.pl/sciezki

[10] http://www.klubtrenerow. firma2000.pl/blog/indem.php?id=d8alaeey

[11] http://www.pmi.org/ certification.aspx

[12] http://www.pmi.org/Certification/Project-Management-Professional-PMP.aspx

[13] http://www.poddrzewem.pl/do-poczytania/certyfikacja-scrum-wedlug-scrum-alliance

[14] http://www.prince2.akn.pl/Prince2_program.pdf

[15] http://www.szkolenia.com.pl/index/artykul/29.

[16] https://www.scrumalliance.org/certifications/Practitioner

\section{COMPARATIVE ANALYSIS OF THE APPROACHES TO THE PROJECT MANAGEMENT}

Nowadays, the project management is an important part of the activity in different types of organizations, beginning from businesses, either by the non-profit organizations and ending on the public institutions. In countries have developed a project culture, based on both general and specific methodologies, optimized for the specific industries. Contemporary project competences constitute an important part of the education of the managers. They are also a factor which is very often evaluated in job interviews.

This paper presents a comparative analysis of selected generic methodologies and approaches to project management. Realizing it, there have been identified interesting dimensions for comparisons, important both from the point of view of individual career development of the project manager and processes of project management as well. The authors' intention is not to find the most appropriate solution, because it must be adapted to the conditions and specific needs of the organization. But it sought to present information in a con- 
centrated manner so as to facilitate conscious and purposeful selection of individual approaches.

The article consists of an introduction, in which reference is made to the origin of project management. Then it shows the specifics of the project and the requirements that arise from it in relation to the management processes. In the following sections of the paper there is presented a comparison of linear, classical approaches stemming from the so-called agile approaches, well known in IT industry. Then there were compared in detail the selected concepts of project management. It is taken into account mainly an aspect of training, and process of developing the project competences. The article finishes with a summary of the conducted comparisons. It also identifies limitations associated with the selection of appropriate approach.

Keywords: project management, PMI, PRINCE2, IPMA, scrum.

DOI: $10.7862 /$ rz.2015.mmr.48

Tekst złożono w redakcji: wrzesień 2015

Przyjęto do druku: październik 2015 